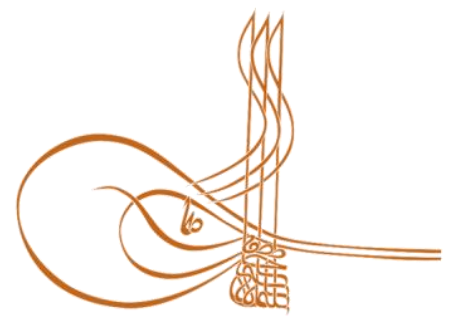

www.turkishstudies.net/economy
Turkish Studies - Economics, Finance, Politics

eISSN: $2667-5625$

Research Article / Araştırma Makalesi

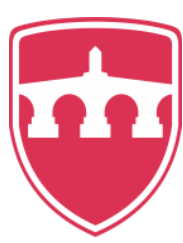

INTERNATIONAL BALKAN

UNIVERSITY

Sponsored by IBU

\title{
Öğrencilerin Yatırım Davranışlarını Etkileyen Duygusal ve Psikolojik Faktörler: Giresun Üniversitesi İİBF İşletme Bölümü Öğrencileri Üzerine Bir İnceleme
}

\author{
Emotional and Psychological Factors Affecting Students' Investment Behaviors: A Research on \\ Giresun University Faculty of Economics and Administrative Sciences Departments of Business \\ Administration' Students
}

\author{
Alper Karavardar* - Yeliz Şahintürk ${ }^{* *}$
}

\begin{abstract}
The economic and financial theories that are developed to conceptualize financial decisions and financial markets are based on the definition of rational economic behavior that focuses on utility maximization. The classical finance approach implies that investor behaves rationally in the efficient markets and it does imply any transaction cost. A fundamental economic assumption "homo economicus" definition is in fact that does not reflect human nature and human behavior. Anomalies in the financial markets have led to the questioning of theories in economics and finance literature. In this context behavioral finance responds to classical finance paradigms with the maximization of investor satisfaction level. Behavioral finance tries to explain decision making under uncertainty with the help of psychology, sociology and anthropology. In real life, investors are influenced by emotional, psychological, and sociological factors when making their decisions. For this reason, behavioral finance has become an attractive topic in the last thirty years. In this study, the emotional and psychological factors influencing students of the Giresun University FEAS department of business administration when investing were examined. Within the scope of the study, it was determined that there are four important factors affecting students' investment decisions by performing factor analysis. According to factor analysis, there are four important factors that affect students' investment decisions. The first factor affecting students' investment decisions is their "personality traits". The second factor affecting individual investment decisions is "the person's attitude toward risk". The third important factor for decision makers is "the relationship between investment instruments and social interaction". The last factor affecting students' choice of investment was determined as is "the relationship between investment instruments and media".
\end{abstract}

\footnotetext{
* Doç. Dr., Giresun Üniversitesi, İktisadi ve İdari Bilimler Fakültesi, İşletme Bölümü

Assoc. Prof. Dr., Giresun University, Faculty of Economics and Administrative Sciences, Department of Business ORCID 0000-0001-7330-4038

akaravardar@yahoo.com

*** Yüksek Lisans Öğrencisi, Giresun Üniversitesi, İktisadi ve İdari Bilimler Fakültesi, İşletme Bölümü MBA Student, Giresun University, Faculty of Economics and Administrative Sciences, Department of Business ORCID 0000-0001-5474-736X

ylzz1994@gmail.com

Cite as/ Atıf: Karavardar, A., Şahintürk, Y. (2020). Öğrencilerin yatırım davranışlarını etkileyen duygusal ve psikolojik faktörler: Giresun Üniversitesi İ̈BF işletme bölümü öğrencileri üzerine bir inceleme, Turkish Studies Economy, 15(1), 687-704. https://dx.doi.org/10.29228/TurkishStudies.40222

Received/Geliş: 18 December/ Aralık 2019 Checked by plagiarism software

Accepted/Kabul: 25 March/Mart $2020 \quad$ Published/Yayın: 30 March/Mart 2020

Copyright (C) INTAC LTD, Turkey

CC BY-NC 4.0
} 
Structured Abstract: There are many factors that affect individuals' investment preferences. Behavioral finance is an approach that helps to reveal the factors that affect investors' financial preferences. The discovery of cognitive processes that affect investor behavior is an important subject of research. Individuals 'education on finance is expected to have an impact on individuals' financial preferences. However, individuals interact intensely with the social environment in which they live. Similarly, the psychological states of individuals have an impact on investment and spending preferences. The discovery of cognitive processes that shape investment decisions of individuals is closely related to the effectiveness of financial markets. In developing countries, how investment decisions are made is important for sustainable development. In this study, it is aimed to reveal the emotional and psychological factors that affect the investment forms and decision making processes of university students as investors. Students studying in the Business Administration department take various courses on finance. Therefore, their awareness of finance issues is higher compared to students studying in other departments. For this purpose, the evaluations of Giresun University Faculty of Economics and Administrative Sciences business administration students on this subject were examined. Gümüş et al. (2013) studies of the investors in Turkey and Azerbaijan have tried to determine whether they remain under the influence of some factors that make investment decisions. They used the survey method in their studies. As a result of the survey, they revealed that some psychological factors were effective on the decisions taken by Turkish and Azerbaijani investors. Kendirli \& Kaya (2015) examined the decisions of individual investors in the provinces of Çorum and Yozgat, whose development levels are different cities and they examined the demographic and psychological factors that affect their decisions. In their studies using the survey method, they determined that the investment tools used by the investors in Çorum and Yozgat provinces are similar. However, they determined that some factors that affect investment decisions differ. In their study, Aytekin \& Aygün (2016) examined traditional finance theories and the factors that led to the emergence of behavioral finance. In their study, Öztopçu \& Aytekin (2017) examined how and why the concept of behavioral finance emerged, investment tools and the factors that investors were affected when making their decisions and their behavior.

Within the scope of the research, survey method was used as data collection technique. Survey questions are taken from the article titled "Behavioral biases of finance professionals: Turkish evidence" by Kiymaz et al. (2016). The questionnaire form used in the research consists of questions regarding students' demographic characteristics and cognitive bias. The questionnaire includes 30 questions and 5-point Likert scale was used. The data obtained were analyzed with SPSS 21 Statistics Program. According to the result of factor analysis, there are four important factors that affect students' investment decisions. The first of these is "personality traits". The personality traits of students are very effective in investment decisions. The second is "the person's attitude towards risk". Students' individual perceptions of risk when making their investment decisions, their individual risk preferences, in other words, their attitudes towards risk, have an impact on their investment decisions. The third one is "the relationship between investment tools and social interaction". While investing, students are influenced by the relationship of investment tools and social interaction. The fourth is the "media relationship with investment tools". While the students are investing, they are affected by the types of investment instruments, their way of being in the media, and thus the social interaction of the related investment instruments. According to the findings of the study, it is seen that students are significantly affected by their personality traits when making investments. The personality traits of the individual are very effective in perceiving risk and making decisions. The risk perception and investment decision of an ambitious investor differs from unambitious investor. This situation is related to investors 'risk preferences and is a differentiation based on individuals' past experiences and perceptions. Similarly, optimism is an important determinant of financial decisions. An optimistic investor overestimates his / her own views and thoughts, his knowledge, and sees the probability of the results to be bad, and thus the risk. From the perspective of a pessimistic investor, the situation is the opposite. For these reasons, the difference in the risk perceptions of the two investors causes differentiation in investment decisions. Students' attitude towards risk is an important and influential factor on investment preferences. While making the decisions of the investors, it can be said that the effect of the risk factor is quite high. Investors' attitude towards risk and the way they perceive risk affect their financial decisions. As a result of the study, it has been determined that university students are affected by the relationship between social investment and related investment tools. Individuals, who are social entities, are increasingly engaged in social interaction, especially in the century we are in. Individuals are influenced by their community and their environment. Individuals learn the behavior of people living in their environment and can act according to herd psychology when making decisions. Individual investors take the ideas of their families and friends when deciding which investment instrument to invest and they decide by sharing information with them. They decide by sharing 
information with them. In this context, the level of socialization of investors has a significant impact on their preferred investment tools. According to the findings of the study, the relationship between investment tools and the media has been seen to be one of the most important factors that students are affected when making investments. Media, which can be described as written and visual mass media, greatly affects people's behavior. When the findings of the study are taken into consideration, it is seen that the university youth is more intensely affected by the interaction in question. When the findings of the study are taken into consideration, it is seen that university youth is significantly affected by social media. Similarly, in the study, it was determined that there was a significant relationship between the students 'ages and the degree of students' exposure to the news related to the political developments in the media. Again, a significant relationship has been determined between the ages of the students and the degree of students being affected by international economic and financial developments and company reports. In addition, a relationship was found between the students' ages and their opinions on the risk status of their investment funds, deposit accounts and stocks. In terms of comparability of study results, it would be useful to apply the same study to students studying in business departments of different universities.

Keywords: Behavioral Finance, Cognitive Biases, Investment Decisions, University Students

Öz: Finansal kararlar ve finans piyasalarını kavramaya yönelik olarak geliştirilmiş ekonomi ve finans teorileri, fayda maksimizasyonu odaklı rasyonel ekonomik davranış tanımına dayanmaktadır. Klasik finans yaklaşımı yatırımcıların etkin piyasalarda rasyonel davrandıklarını, her hangi bir işlem maliyetinin söz konusu olmadığını belirtmektedir. Temel bir iktisadi varsayım olan "homo economicus", gerçekte insan doğasını ve insan davranışlarını yansıtmayan bir tanımlamadır. Finans piyasalarındaki anomaliler, ekonomi ve finans yazınında yer alan teorilerin sorgulanmasına neden olmuștur. Davranıșsal finans bu bağlamda klasik finans paradigmalarına yatırımcıların tatmin derecelerinin maksimizasyonu düşüncesi ile cevap vermektedir. Davranışsal finans, belirsizlik altında karar verme sürecini psikoloji, sosyoloji ve antropolojinin yardımıyla açıklamaya çalışmaktadır. Gerçek hayatta yatırımcılar kararlarını verirken duygusal, psikolojik ve sosyolojik faktörlerden etkilenirler. Bu nedenle son otuz yıllık süreç içinde davranışsal finans dikkate çekici bir konu başlığı haline gelmiş̧tir. Bu çalışmada Giresun Üniversitesi İ̈BF İşletme Bölümü öğrencilerinin yatırım yaparken etkilendikleri duygusal ve psikolojik faktörler incelenmiştir. Çalışma kapsamında faktör analizi yapılarak öğrencilerin yatırım kararlarını etkileyen dört önemli faktör olduğu belirlenmiştir. Faktör analizi sonucuna göre öğrencilerin yatırım kararlarını etkileyen dört önemli faktör mevcuttur. Öğrencilerin yatıım kararlarını etkileyen faktörlerden birincisi "kişilik özellikleri” 'dir. Bireysel yatırım kararlarını etkileyen ikinci faktör ise "kişinin risk karşısındaki tutumu Öğrencilerin yatırım araçları tercihlerini etkileyen son faktör ise "yatırım araçları ile medya ilişsisi" olarak belirlenmiștir dur. Karar alıcılara açısından üçüncü önemli faktör "yatırım araçları ile sosyal etkileşim ilişskisi”'dir. Öğrencilerin yatırım araçları tercihlerini etkileyen son faktör ise "yatırım araçları ile medya ilişsisi" olarak belirlenmiştir.

Anahtar Kelimeler: Davranışsal Finans, Bilişsel Önyargılar, Yatırım Kararları, Üniversite Öğrencileri

\section{Giriș}

Karar alma eylemi, özü itibariyle bir süreci tanımlamakta olup bireylerin karşılaştıkları bir sorunla bağlantılı olarak, kendi amaçları doğrultusunda alternatifler arasından birini bilinçli olarak tercih etmesidir. Karar alma eyleminin karmaşıklığı bir süreç olarak çok boyutluluk arz etmesinin bir sonucudur. Bireyler açısından bakıldığında sorunların çözümünde sınırlı bir zaman diliminde hareket edilmesi mecburiyeti, geleceğe ilişkin muhtelif öngörülere dayalı olması, sınırlı bilgi ve iletişim gibi kısıtlamalar karar verme davranışını belirleyen çerçeveyi oluşturmaktadır. Bilginin kısıtlılığı, karar verenin içinde bulunduğu sınırlama ve çatışmalar, tatmin edici bir davranış oluşturulmasının önündeki engellerden sadece bir kaçıdır. Klasik rasyonel karar verme modeli, bireylerin söz konusu soruna ilişkin tüm seçenekler ve bu seçeneklerin olası sonuçları hakkında bilgi sahibi olduğu varsayımına dayanmakla birlikte bu varsayımın gerçek hayatla özdeş olmadığı bir gerçektir. Gerçek dünya koşulları dikkate alındığında karar alıcılar açısından sınırlı bir rasyonellik söz konusudur. Sınırlı rasyonellik sadece sınırlı bilginin bir diğer ifade ile belirsizliğin bir sonucu olmayıp insanın sosyolojik ve psikolojik doğası ile de ilintilidir. Simon (1987) ve Daft 
(2010) içsel ve çevresel kısıtların önemini belirterek birçok bilişsel kısa yol, önyargı ve kişisel değerlerin bireylerin davranışlarını etkilediğini ifade etmişlerdir.

Klasik finans yaklaşımında karar alıcıların beklenen faydalarını maksimize etmeleri şeklinde tarif edilen rasyonel davranış/tercih, Daniel Bernoulli (1738) tarafindan oluşturulan "beklenen fayda teorisi" ' ile vücut bulmuş olup, Adam Smith'in (1776) duygulardan arındırdığ varsayımsal birey "homo economicus" tanımı üzerine kuruludur. Buna göre belirsizlik altında karar verme durumunda olan birey, sorun ile ilgili tüm bilgiye sahiptir ve önyargılardan uzak bir biçimde her bir tercih alternatifinin risk ve beklenen faydasını olasılıklar ile ağırlıklandırarak karşılaştırır. $\mathrm{Bu}$ anlayışta her bir alternatifin muhtemel sonucu birer fayda fonksiyonu oluşmaktadır. Bireyin tatmin derecesi ölçülebilir, kardinal (sayısal) faydadır. Karar vericiler açısından elde edildiğine inanılan doyum olarak da tanımlanabilecek fayda kavramı, her ne kadar sayısallaştırılmaya çalışılsa da esasen sübjektif karakterlidir ve dolayısıyla karar verici durumundaki bireyin içinde bulunduğu sosyo-ekonomik ve psikolojik durum ve algılamaları ile şekillenir. Bernoulli'nin (1738) teorisi, St.Petersurg Paradoksunu açıklamaya yönelik bir gayret olsa da, bireylerin risk tercihlerini bütünüyle açıklayabilme konusunda yetersiz olmuş beraberinde Allias Paradoksu (1953) \& Ellsberg Paradoksu (1961) gibi başka sorunlar ortaya çıkarmıştır. J. Maurice Clark (1918:4) bu durumu "bir iktisatçı psikolojiyi görmezden gelmeye çalışabilir, fakat insan doğasını görmezden gelmek onun için bir imkânsızlıktır, çünkü iktisat bilimi insan davranışları bilimidir" sözleriyle özetlemiştir. Clark (1918) insan davranışının psikolojik varsayımlar içerdiğine değinerek klasik finans ve iktisattaki “çıkar maksimizasyonu” deyimi yerine "memnuniyetin maksimizasyonu” deyiminin kullanılabileceğini belirtmiştir. Clark (1918:7) akılcı seçim anlayışının bireyin zihinsel yaşamının küçük ve oldukça da kusurlu bir parçası olduğuna işaret etmiştir.

Eugene F. Fama'nın (1970) istikrarlı bir piyasada bilginin süratle fiyatlara yansıdığ1, arbitraj imkânının bulunmadığı bu itibarla fiyat değişimlerinin tahmin edilemeyeceğini ve rassal yürüyüsse uygun olduğu şeklinde özetlenebilecek olan 'Etkin Piyasalar Hipotezi (EPH) " esasen borsadaki hisse senetlerinin fiyat değişimlerine odaklanarak oluşturulmuş, modern finansın önemli tanımlamalarından biridir. EPH, fiyatların rassal yürüyüş modelini takip ettiğini, rassal yürüyüşün ise martingale süreçler kapsamında yer aldığını ve bu nedenle her iki özelliğin adil oyun sonucunu doğurduğunu yani mevcut fiyatların yatırımcıların beklentilerini yansıtması nedeniyle olağan üstü kazançların söz konusu olamayacağını belirtmektedir. Fama (1970) yatırım stratejilerinin içerdikleri sistematik riskleri getirinin karşılığı olarak değerlendirmiş, yatırım tercih ve hareketlerinin piyasada düzeltici bir etki oluşturduğunu ifade etmiştir. EPH basit olarak piyasa etkinliğinin artmasının, yatırımcıların başkalarının hatalarından faydalanma imkânını yok ettiğine işaret ederek (Uronen, 2013) arbitraj imkânlarının süratle değerlendirildiği dolayısıyla fiyatların bilginin yansıması olduğu görüşü üzerine kuruludur. Arbitraj, bir ekonomik varlığın tüm piyasalarda geçerli, tek bir fiyatının olduğu düşüncesi “Tek Fiyat Kanunu”' (Seyidoğlu, 2001;100) esasına dayalı olup, risksiz getiri sunan maliyetsiz bir işlem, reel davranışlar tarafindan yönetilen bir karar alma faaliyetidir. EPH ilerleyen yıllar içerisinde piyasa anomalilerini açıklanmak hususunda yetersiz kaldığı eleştirilerine maruz kalmıştır. 'Rasyonel Beklentiler Hipotezi'”nin bir uzantısı olarak değerlendirilebilecek EPH'nin (Shleifer, 2000) temelinde yer alan Tek Fiyat Kanunu'nun geçerliliği konusunda birçok çalışma mevcuttur (bu çalışmaların literatürde, "sinır etkisi" (Knether, 1983; Engel \& Rogers, 1996, Parsley \& Wei, 2001; Olper \& Raimondi, 2008), "eşik etkisi"' (Dixit, 1989; Tong, 1990, O'Connell \& Wei, 2002; Sarno, Taylor \& Chowdhury, 2004, , Chen vd, 2014, Huber 2016) ve "piyasa fiyatlamas1" (Krugman, 1987; Dornbusch, 1987; Knetter 1993, Ghosh \& Wolf, 1994; Betts \& Devereux, 2000; Rogoff vd. 2001, Cochrane, 2011, Gözgör, 2015) başlıkları altında özetlendiği görülmektedir). EPH, varsayım olarak eş zamanlı simetrik bilgi düşüncesine dayanmakta birlikte finansal bilgilerin gerçekte asimetrik nitelikte olması ve yanlış fiyatlamayı bertaraf edecek finansal eylemlerin gerçek hayatta risk ve maliyetleri olması nedeniyle üzerinde tartışılan bir düşüncedir. 80’li yıllara kadar yapılan ampirik çalışmalarla 
geniş biçimde desteklenen Fama'nın bu düşüncesi daha sonraları kamuoyuna aktarılan bilgilerin fiyat hareketleri üzerinde sinırlı bir etkisinin bulunması (Cutler vd., 1989) varlık fiyat ve getirilerinin rassal yürüyüş tanımlaması aykırı olarak kısmi olarak öngörülebileceği (Ferson ve Harvey, 1993) nedeniyle eleştirilmiştir. Porta vd., (1997) eksik bilgi altında verilen yatırım kararlarını inceleyerek varlıkların fiyat hareketlerinde davranış ve psikoloji bilimleriyle ilişkili olduğunu, Barberis vd. (1998) yatırımcıların yatırımları hakkındaki iyi veya kötü haberlere verdikleri aşırı sert veya aşırı yumuşak tepkiyi, Kahneman \& Tversky'e (1974) atıf yaparak, muhafazakarlık (yatırımcının yeni verilere karşı tutucu davranması) ve temsiliyet (yatırımcının kendini bir gruba ait görmesi) kavramları üzerine kurulu psikolojik model ile açıklamaları, davranışsal finansın tartışılmaya başlanmasına neden olmuştur.

Akademik yazın incelendiğinde davranışsal finansın EPH sonrasında önemli ölçüde ilgi çeken bir araştırma başlığı olduğu görülmekle birlikte kökenlerinin çok daha eskilere dayandığı söylenebilir. Gabriel Tarde, 19 yy.'’n sonlarında yaptığı çalışmalarla, bireylerin sübjektif nitelikli tutum ve davranışlarının bireyler arasındaki aktarımına dayalı olarak geliştirdiği "ekonomik psikoloji kuramı"' (Adjukovic vd.,2018:5) ekonomik davranışların psikolojik mekanizmalarla ilintili olduğu ifade etmiştir. Tarde'nin kuramı (1902) iki yönlüdür. Tarde ekonomik psikolojinin, hem psikolojik mekanizmaların ekonomik davranışları etkilediğini hem de ekonomik olayların psikolojik etkilerinin olduğunu belirtmiştir. Aslen bir sulh yargıcı olan Tarde (1902) "Psychologie Economique" adlı kitabında "homo economicus" tanımlamasının tüm duygu ve inançlardan soyutlanmış münhasıran metodolojik çıkarları takip eden bir varsayımsal insan olarak, sadece eksik bir tanımlama değil aynı zamanda bir çelişki anlamına geldiğini ifade etmiştir. Tarde (1902:85) "kendi kalbi, inanç ve gururu ile ilişkisini tamamıyla kesmiş, en çok çıkarlarını ön planda tutan bu adam kimdir?"' demiştir. Tarde'nin temelleri attığı davranışsal finans, uzun yıllar sonra Tversky ve Kahneman'ın 2002 yılında Nobel ödülü alan çalışmaları "Psikolojik araştırmalarda ortaya çıkan bulguların ekonomi bilimine entegrasyonu ve belirsizlik karşısında karar verme" ile zirve noktasına gelmiştir.

Bireylerin yatırımlarla ilgili karar verme süreçlerinde rasyonel olmayan davranış kalıpları takip etmeleri her ne kadar ilk defa 19 yy sonlarında tartış1lmaya başlansa da (Le Bon, 1896) gerçek anlamda finans disiplinin de Simon'un (1967) "sınırlı rasyonalite" tanımlaması ile vücut bulduğu söylenebilir. Geleneksel finans anlayışına göre, yatırımcılar yatırım kararları alırken rasyonel davranırlar. Yatırımcıların beklentileri, özellikleri aynıdır. Yatırımcıların hepsi maksimum faydayı hedefler, piyasalar ise etkindir. Menkul kıymet fiyatları çoğu zaman tesadüfen oluşur (Gümüş vd. 2013: 75). Geleneksel finans modellerinin yetersiz kaldığı zaman Davranışsal Finansa karamı ortaya çıkmıştır. Davranışsal finansa göre yatırımcılar rasyonel değil irrasyonel davranışlar sergiler ve her yatırımcının özellikleri beklentileri farklıdır. Piyasa etkin değildir ve yatırımcılar yatırım kararları alırken psikolojik ve duygusal faktörlerden etkilenirler. Bu çalışmada davranışsal finans bağlamında, Giresun Üniversitesi İ̈BF işletme bölümü öğrencilerinin yatırımc1 davranışlarını ve yatırım yaparken etkilendikleri duygusal ve psikolojik faktörleri incelemektir. Bu amaçla 2017-2018 güz yarıyılı Giresun Üniversitesi iktisadi ve idari bilimler fakültesi işletme bölümü öğrencileri arasında anket uygulanmıştır. Çalışma kapsamında elde edilen cevaplar incelenmiş, soruları özensiz yanıtlayan ve boş bırakan anketler analize dâhil edilmemiş ve toplamda 250 anket değerlendirilmiştir.

\section{Davranışsal Finans Literatürü}

Gümüş vd. (2013) yapmış oldukları çalışmalarında Türkiye ve Azerbaycan'daki yatırımcıların bazı faktörlerin etkisinde kalarak yatırım kararlarını alıp almadıklarını tespit etmeye çalışmışlardır. Anket yöntemi kullandıkları çalışmalarında onlar her iki ülkede 384 kişiye anket uygulamışlardır. Çalışma sonucunda Türk ve Azeri yatırımcıların aldıkları kararlar üzerinde bazı psikolojik faktörlerin etkili olduğu ortaya çıkmıştır. Aren vd. ise 2014 yllında gerçekleştirdikleri araştırmalarında klasik finanstan farklı olarak ortaya çıkan davranışsal finans inceleyerek 
davranışsal finansın klasik finansı tamamen reddetmediğini sadece piyasada finansal kararlar alınırken psikolojik faktörlere de yer verilmesi gerektiğini belirtmişlerdir. Yeşildağ \& Özen (2015) yapmış oldukları bir araştırmada Uşak ilindeki borsa yatırımcılarının profilini belirleyip kararlarını etkileyen demografik ve sosyo-ekonomik faktörlerin ortaya konulması ve yatırımcıların yatırım kararlarını verirken rasyonel hareket edip etmediklerini tespit etmeye çalışmışlardır. Borsa yatırımcılarına anket uygulanmış olup elde edilen veriler tek yönlü anova testi ile analiz edilmiştir. Çalışmanın sonucunda Uşak ilinde yaşayan borsa yatırımcılarının profili ile Türkiye'deki borsa yatırımcılarının genel profili arasında benzerlik olduğu yani birbirine çok yakın olduğu ortaya çıkmıştır. Yatırımcıların fazla bilgiye sahip olmadıklarından dolayı özellikle borsa yatırımı konusunda rasyonel hareket etmedikleri, yatırım kararlarını verirken demografik ve sosyoekonomik faktörlerden etkilendikleri tespit edilmiştir. Kendirli \& Kaya (2015) yapmış oldukları çalışmada, gelişmişlik düzeyleri farklı olan Çorum ve Yozgat illerindeki bireysel yatırımcıların kararları ve kararlarında etkili olan demografik ve psikolojik faktörler incelenmişlerdir. 400 bireysel yatırımcıya uygulanan anket çalışmasında, söz konusu iki il arasındaki farklılıkların, yatırım kararlarını etkileyen faktörler içinde yer alacağı düşünülerek geliştirilen hipotezler kantitatif analiz teknikleri ile test edilmiştir. Çalışmanın sonucuna göre Çorum ve Yozgat illerindeki yatırımcıların yatırım araçları benzerlik gösterirken, yatırım kararlarını etkileyen bazı faktörler farklılık göstermektedir. Tekin (2016) çalışmasında, firmalarda alınan finansman kararlarına davranışsal açıdan yaklaşmış olup çalışmada karar vericilerin finansman kaynağı tercih ederken yatırımcının kendine aşırı güven durumu ile ve kayıptan kaçınma durumu dikkate alınmıştır. Anket yöntemi kullanılan çalışmada İstanbul'da ticaret ve sanayi odalarına kayıtlı 255 küçük ve orta büyüklükteki işletmeler değerlendirmeye alınmıştır. Çalışma sonucunda firmalarda finansman kararlarını veren kişilerin kendine aşırı güvenli ve kayıptan (riskten) kaçınan bireyler oldukları tespit edilmiştir. Buna göre KOBİ sahiplerinin veya yöneticilerinin verdikleri finansman veya sermaye yapısı kararları, davranışsal önyargı düzeylerine göre farklılık gösterebilmektedir. Aytekin \& Aygün (2016) yaptıkları çalışmada geleneksel finans teorilerini ve davranışsal finansın ortaya çıkmasına neden olan faktörler irdelenmiştir. Aytekin \& Aygün (2016) bilişsel ve duygusal faktörler finansal piyasalarda önemli bir yere sahip olduğunu belirterek, davranışsal finansın bireylerin yatırım kararlarına ve genel piyasa durumuna olumlu katkılar sağlayabileceğini belirtmişlerdir. Hamurcu ve Aslanoğlu (2016) bilgi teknolojileri ve iletişim sektörü çalışanlarına bir anket çalışması yaparak, elde edilen veriler üzerinde faktör analizi gerçekleştirmek suretiyle piyasalardaki davranışsal finans eğilimlerinin etkileri incelemişlerdir. Öztopçu \& Aytekin (2017) yaptıkları çalışmada davranışsal finans kavramının nasıl ve neden ortaya çıktığı, yatırım araçları ve yatırımcıların kararlarını verirken etkilendikleri faktörleri ve gösterdikleri davranışlarını incelemişlerdir. Balıkesir ilinde yaşayan bireysel yatırımcılara kararlarını verirken gösterdikleri davranışsal eğilimleri ortaya çıkarmak amacıyla bir anket çalışması yapmışlardır. Çalışma sonucunda Balıkesir ilinde yaşayan bireysel yatırımcıların davranışsal finans eğilimlerini önemli ölçüde gösterdikleri belirtmişlerdir. Gül vd. (2017) çalışmalarında, yatırımcı davranışlarını, aşırı iyimserlik, aşırı güven, kayıptan kaçınma, pişmanlıktan kaçma ve temsil etme eğilimi olarak toplam beş boyut altında incelenmişlerdir. Gaziantep kuyumcular odasına kayıtlı 63 kuyumcu ile anket yapılarak gerçekleştirilen araştırma sonucunda yatırımcı davranışlarının yaşa, medeni duruma ve sermaye tutarına göre farklılık göstermediği, bununla birlikte yatırımcı davranışlarının eğitim, firmanın yaşı ve mesleki tecrübeye göre farklılık gösterdiğini tespit etmişlerdir. Öncü \& Özevin (2017) çalışmalarında kadınların yatırım yaparken gösterdikleri davranışları etkileyen psikolojik faktörleri araştırmayı amaçlamışlardır. Anket yöntemi kullanılan çalışmada, rastgele örnekleme yoluyla seçilmiş 300 kadına uygulanan anket verileri frekans analizi ile irdelenerek kadınların yatırım yaparken psikolojik faktörlerden etkilenerek hareket ettikleri ve karar verdikleri tespit edilmiştir. 
Şekil 1: Yatırımcı Davranışlarını Etkileyen Duygusal ve Psikolojik Faktörler

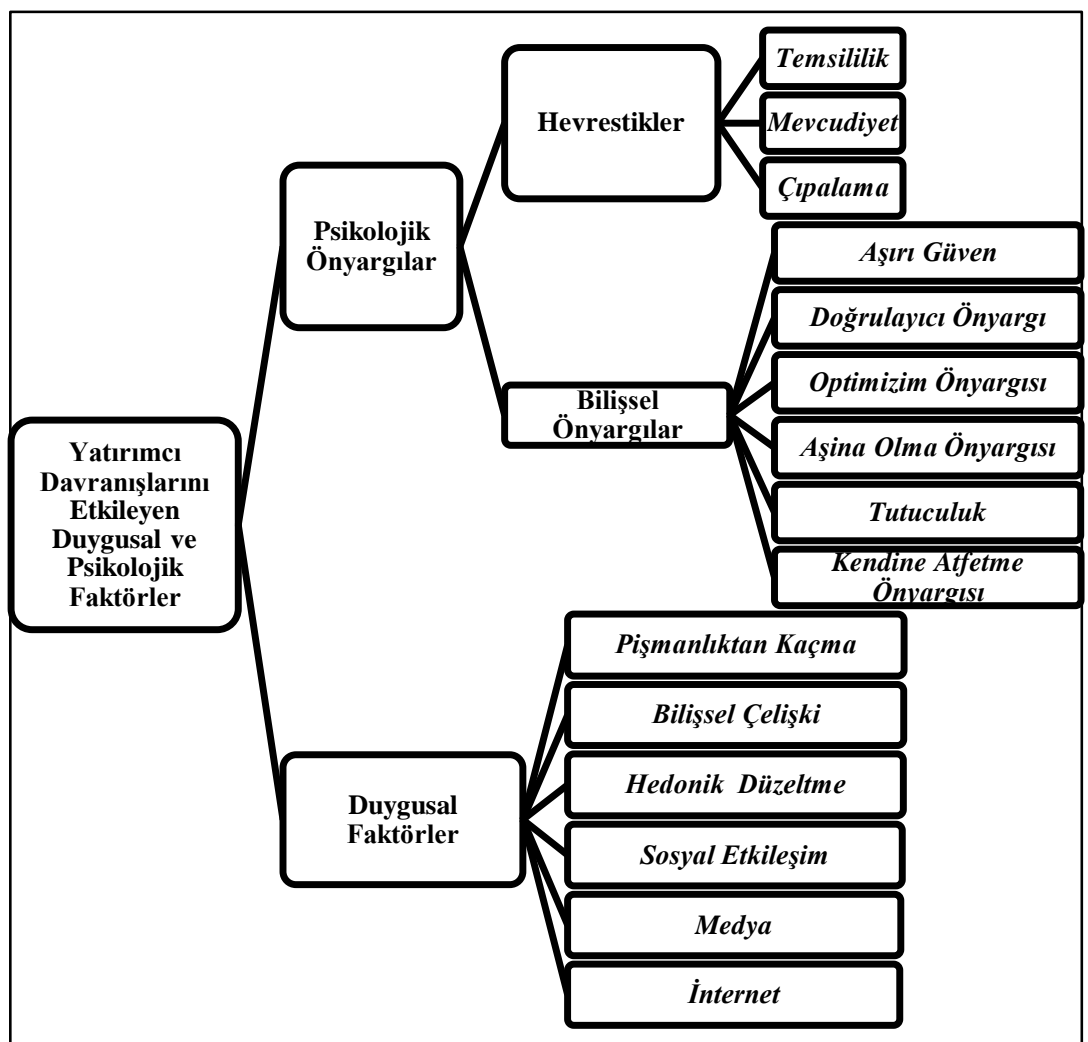

\section{Psikolojik Önyargılar}

Önemli bir karar vermek riskli girişimler arasından tercih yapmaktır çünkü olasılıkların sonuçları bilinemez ve bireyler bu olasılıklar ile ilgili kararlar verirler. İnsanlar sonuçlara değer yükleyerek değerlemeler ve riskli seçenekler ile ilgili inanışlarına göre tercihler yaparlar. Kararlar birçok yönden hatalı ve yanlış olabilir. Bu hatalara da kısaca önyargılar tanımlanabilir (Kahneman \& Riepe, 1998: 1-2).

\subsection{Hevrestikler}

Bireyler karar verirken bilişsel kestirme yollar kullanmakta olup karar alıma sürecinde bilgileri söz konusu bu kısa yollarla değerlendirirken, deneyimlerinden faydalanmaktadır (Gürsoy, 2014: 869). Söz konusu bilişsel kısa yollar şu şekilde sıralanabilir;

Temsililik: Bir olayı veya kişiyi değerlendirirken başka bir olay veya kişi tarafından temsil edilip edilmediğine bakılarak değerlendirilmesini ve en çok göze çarpan unsurlardan etkilenerek karar vermesini ifade eder. Bu etki ile yatırımcı piyasada oluşan ve devam eden durumu genelleme yaparak değerlendirir ve söz konusu genellemeyi kararlarına uygular. Bu durum yatırımcının piyasa koşullarına aşırı tepki göstermesine neden olmaktadır. Aşırı tepki, yatırımcıların yeni bilgilere daha çok ağırlık vererek bu bilgileri önemsemesi ve eski bilgileri ise göz ardı ederek, dikkate almamasını ifade eder (Sansar, 2016; 142).

* Mevcudiyet Önyargısı: Yatırımcılar mevcudiyet hevristikinin etkisiyle kararlarında, bazen diğer bütün istatistiki bilgileri göz ardı ederek, ekseriyetle çarpıcı ve dikkat çeken bilgilerin etkisine kapılmaktadırlar. Özellikle finansal piyasalarda zaman zaman büyük puntolarla dikkat çekici bir şekilde verilen bilgiler piyasalarda aşırı reaksiyon yaratmaktadır (Hayta, 2014: 333). 
* Çıpalama Önyargısı: Çıpalama, bireylerin ilk gelen bilgiye takılı kalması ve sonradan gelen bilgilere adapte olamaması durumudur. Bireyin değişen şartlara ayak uyduramamasina neden olmaktadır (Sansar, 2016: 143). Belirsizlik altında bireyin karar verebilmesi için bir referans noktasına ihtiyacı vardır. Referans noktası, bir durumu ya da değişimi değerlendirmek amacıyla dikkate alınan temel bir konumdur. Finansal piyasalarda hisse senedi fiyatları referans noktası olup, fiyatların sabitlenmesine ise çıpalama denilebilir (Hayta, 2014: 334).

\subsection{Bilişsel Önyargılar}

Bilişsel yanlılıklar, belirsizlik altında insanların bilişsel sınırlılıklarının üstesinden gelmesine yardımcı olur ve karar almalarını kolaylaştırır. Bir diğer ifade ile karar verme durumunda olan birey açısından çok zaman alıcı ve zorlu bir değerlendirmeyi basitleştirici bir işleve sahiptirler. Ancak karar alıcıların detaylı bir şekilde değerlendirme yapmadan yargıda bulunmaları, bireyleri irrasyonel sonuçlara götürebilmektedir (Tomak, 2011: 74). Karar alıcıları irrasyonel değerlendirme yapmaya iten faktörler aşağıdaki gibi özetlenebilir;

Aşırı Güven: Yatırımcıların tahmin etme kabiliyetlerini abartmalarına sebep olur. Aşırı güvene sahip olan yatırımcılar çok fazla menkul kıymet alıp satarlar (Tufan, 2008: 54). İnsanlar kişisel kabiliyetlerine ve bilgilerine fazla güvenirler. Bundan dolayı riskleri daha düşük görmekte ve durumu kontrol edebileceklerini düşünmektedirler (Sümer \& Aybar,2016: 80).

* Doğrulayıcı Önyargı: Bireyler kendi düşünceleri ve kararlarıyla bağdaşmayan bir durumla karşılaştıklarında o durumu görmezden gelirler. Tersi durumda yani kendi düşüncelerini ve kararları yönünde bir durumla karşılaştıklarında ise bu durumu önemseyen tutum geliştirirler (Gürsoy, 2014: 875).

Optimizm Önyargısı: İyimser yatırımcılar, kendi kabiliyetlerini ve bilgilerini oldukça abartma ve sonuçların kötü olma olasıllğını düşük görme eğilimi içindedirler. İyimser yatırımcılar şans faktörüne inanmazlar, olayları konrol edebileceklerini inanırlar ve riskleri olduklarından daha az olduğunu düşünürler (Kahneman \& Riepe, 1998: 4).

Aşina Olma Önyargısı: İnsanlar belirsizlik durumunda aşina oldukları şeyleri tercih ederler. İki seçenek arasından seçim yaparken daha aşina oldukları seçeneği seçerler. Aşinalık riski riski düşük göstermekte ve yatırımcının yeterli çeşitlendirmeyi yapamamasına neden olmaktadır (Çelik, 2013: 35).

Tutuculuk: İnsanların yeni kanıtlarla karşılaştıkları zaman bunları görmezden gelip geçmişteki inançlarını kolayca değiştirememesidir. Bu durum düşük reaksiyona neden olur. Bireyler yeni bilgiye tepki gösterirken istatistiki bilgileri önceki inanışlarından daha az değeri görür ve düşük değerleme gösterirler (Barberis vd. 1998: 315). Tutuculuk, mevcut durumu sürdürmeye neden olmakta, bireyin yeni gelişmelere karşı olan tepkilerini mevcut durumun sürdürülmesine yönelik olarak oluşturmalarına neden olur. Buna göre bireyler kendi düşüncelerini kolay kolay değiştirmezler ve mevcut olan durumu sürdürme eğilimi gösterirler (Kıyılar \& Akkaya, 2016: 286).

Kendine Atfetme Önyargısı: İnsanlar objektif olmayı deneseler bile bilgiyi kendilerine göre yorumlarlar. Kendi düşüncelerine benzeyen bilgileri önemserken benzemeyen bilgileri önemsemez ve dikkate almazlar. Bu duruma kendini atfetme denilmekte olup, bireyde aşırı güvenin artmasına neden olmaktadır (Prast, 2004: 12). 


\section{Duygusal Faktörler}

Zihinsel süreçlerin ve fiziksel uyarıcıların algılanması sonucunda meydana çıkan hissel davranışlar ve bireylerin karar vermelerinde etkili olan içsel yönelimlerdir. Duygusal faktörlerin sebep olduğu yönelimler, olayların algılanış biçiminin değişmesine ve algılanan bu bilgiler bireylerin tutumlarındaki değişimine neden olabilmektedir. Olumlu durumlar olumsuz şekilde veya olumsuz durumlar olumlu şekilde algılanabilmektedir (Böyükaslan, 2012: 113-114). Bunlara örnek olarak şunlar verilebilir;

Pişmanlıktan Kaçma: Pişmanlık karar verme sürecinde önemli bir faktördür. Çoğu insan düşünmeden vedikleri kararlar sonrası pişmanlıklar yaşarlar. Pişmanlık yoğun ve güçlü bir duygu olup, izleri kolayca atılamayan negatif duygudur. İnsanların ileride pişman olacaklarını düşünerek hareket etmelerine pişmanlıktan kaçınma eğilimi denilmektedir (Böyükaslan, 2012: 117).

Bilişsel Çelişki: Bilişsel çelişki, insanların inanışları ve varsayımlarının yanlış olduğunu gösteren kanıtlarla karşılaştıklarında yaşadıkları zihinsel bir zıtlaşmayı ifade etmektedir. İnsanlar zihinsel olarak tutarsızlık yaşamamak veya bu tutarsızlığı azaltmak için eldeki kanıtları hızlıca inkâr etme yoluna gitmektedirler (Sümer \& Aybar,2016: 81).

Şekil 2: Hedonik Düzeltme İçerik Gösterimi

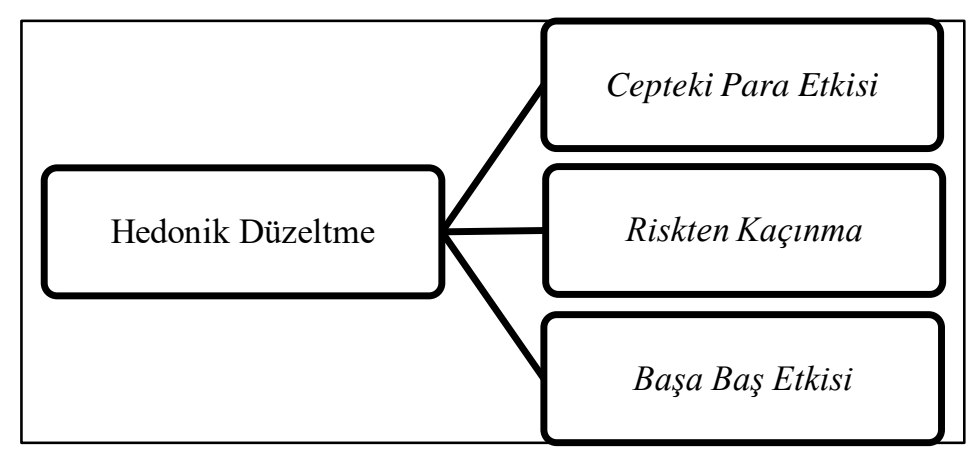

Hedonik Düzeltme: Karar alıcılar, geçmişte almış oldukları kararların sonuçlarından memnun kalırlarsa, sonraki kararlarının olumlu olma olasıllı̆ı̆ıı yüksek görerek hareket edeceklerdir. Bu durumda benzer kararları verirken daha cesur davranacaklar, tam tersi durumda ise yani geçmişte almış oldukları kararların sonuçlarından memnun kalmazlar ise bir sonraki kararlarının olumlu olma olasılığını düşük görerek hareket edeceklerdir. "illk defa yaptığını yatırımdan kisa sürede kar sağlarsınız bir sonraki yatırım kararınızı alırken risk alma dereceniz ne olur?"' sorusu ile bağlantılı muhtelif araştırmalar, birçok yatırımcının daha fazla risk aldığını göstermektedir. Gerçekte ise yatırım kararları birbirinden bağımsızdır ve her biri tek başına değerlendirilmelidir. Burada yatırımcı cepteki para etkisi altında kalmaktadır. Tam tersi bir durum söz konusu olduğunda yani zarar edildiğinde yatırımcılar daha az risk alır. Bu duruma riskten kaçınma denilmektedir. Davranışsal finans alanında yapılan çalışmalarda bireylerin satın aldıkları yatırım araçlarında bir düşüş olduğunda elden çıkartmak için satın aldıkları değere dönmelerini bekledikleri görülmüştür. Bu duruma başa baş etkisi denilmektedir (Gürsoy, 2014: 869-870). 
Sosyal Etkileşim: Bir topluluktaki veya bir gruptaki insanların çoğunluğunun paylaştığı ortak davranışsal eğilimlerdir. Bu eğilimler, insanların düşüncelerini, kararlarını ve davranışlarını etkilemektedir. Sosyal bir varlık olan insan, içinde bulunduğu topluluk ve çevresi ile sürekli etkileşim halindedirler. Topluluklardaki hemen hemen her şey, bu etkileşim ile insanlar arasında yayılır. Toplumlar içindeki bu tür uyumlu bir halde gösterilen davranışlardaki, hareket şekline neden olan sosyal eğilimler, piyasalar üzerinde de etkili olmaktadır (Hamurcu \& Aslanoğlu, 2016: 36).

* Medya: Medya, bireyler üzerinde çok etkin bir güce sahiptir. İnsanların bilgi, duygu, düşünce ve davranışlarını büyük ölçüde etkilemektedir (Kıyılar \& Akkaya, 2016: 304).Günümüzde yatırımcılar BIST endeksindeki değişmeler, bir şirketin hisse başına kazancı gibi haberleri medya aracılığıyla anında öğrenebilmektedir. Uzmanlar, araştırma bölümlerinin hazırlamış olduğu analizleri piyasaya sunmakta, bilgi ve uzman görüşleri medya ile finansal karar alıcılarının dikkatine sunulmaktadır. Uzman görüşleri ile analizlerin yatırımcı davranışlarını üzerindeki etkisi yadsınamaz bir gerçektir (Kıyılar \& Akkaya, 2016: 304).

* İnternet: Günümüzde önemli bir iletişim aracı olan interneti kullanan yatırımcılar daha fazla bilgiye daha hızlı biçimde erişim sağlayabilmektedir. İnternette yer alan bilgilerin ise nitelik olarak her zaman doğru ve aş zamanlı bilgiler olduğunu söyleyebilmek pek mümkün değildir. Bu bağlamda internetin karar alıcılar üzerinde aşırı güven yarattığı ve yatırımcıların daha fazla aktif işlem yaptıkları söylenebilir (Kıyılar \& Akkaya, 2016: 307).

\section{Araștırmanın Metodolojisi}

\subsection{Araştırmanın Amacı}

Araştırmanın amacı üniversite öğrencilerinin birer yatırımcı olarak yatırım biçimlerini ve karar alma süreçlerini etkileyen duygusal ve psikolojik faktörlerin ortaya çıkarılmasıdır. Bu amaçla Giresun Üniversitesi İktisadi ve İdari Bilimler Fakültesi işletme bölümü öğrencilerinin bu konudaki değerlendirmelerinin incelenmesi amaçlanmıştır.

\subsection{Araştırmanın Kapsamı ve Yöntemi}

Araştırma kapsamında öğrencileri finansal karar alıcılar olarak etkileyen faktörlerin belirlenmesine yönelik olarak veri toplama tekniği olarak anket yöntemi kullanılmıştır. Anket soruları Kiymaz vd. tarafindan (2016) yılında yapılan "Behavioral biases of finance professionals: Turkish evidence", adlı makale çalışmasından alınmıştır. Araştırmada kullanılan anket formu, öğrencilerin demografik özelliklerinin yanı sıra bilişsel önyargılar ile ilgili 5'li likert ölçeğine göre düzenlemiş toplam otuz sorudan oluşmuş ve elde edilen veriler SPSS 21 İstatistik Programı ile analiz edilmiştir.

Ankette kullanılan ifadelerin güvenilirliğini ölçmek için yapılan güvenilirlik analizi sonucunda Cronbach's Alpha değeri 0,847 olarak bulunmuştur. Bulunan bu değer, uygulanan anketin güvenilirliğinin yüksek olduğunu göstermektedir (Kalayc1, 2010: 405).

\subsection{Araştırma Bulguları}

Araştırma kapsamındaki elde edilen veriler sırasıyla frekans analizi ve faktör analizi olarak iki ayrı analize tabi tutulmuştur. Tablo1'den görülebileceği üzere ankete katılan öğrencilerin ekseriyetini \% 65,2 ile bayan öğrenciler oluşturmaktadır. Çalışmaya katılan öğrencilerin \% $74,8^{\prime}$ i 21-23 yaşındadır. 


\begin{tabular}{|c|c|c|c|c|c|}
\hline CINSIYYET & FREKANS & $\begin{array}{c}\text { YÜZDE } \\
(\%)\end{array}$ & YAŞ & FREKANS & $\begin{array}{c}\text { YÜZDE } \\
(\%)\end{array}$ \\
\hline $\begin{array}{l}\text { Erkek } \\
\text { Kadın }\end{array}$ & $\begin{array}{l}87 \\
163\end{array}$ & $\begin{array}{l}34,8 \\
65,2\end{array}$ & $\begin{array}{l}20 \\
21 \\
22 \\
23 \\
24 \\
25 \\
28 \\
29\end{array}$ & $\begin{array}{c}10 \\
41 \\
56 \\
90 \\
16 \\
33 \\
3 \\
1\end{array}$ & $\begin{array}{c}4,0 \\
16,4 \\
22,4 \\
36,0 \\
6,4 \\
13,2 \\
1,2 \\
0,4\end{array}$ \\
\hline
\end{tabular}

Çalışma kapsamında elde edilen verilerin değerlendirmesine yönelik olarak faktör analizi gerçekleştirilmiştir. Faktör analizi, birbiriyle ilintili muhtelif sayıdaki değişkenler ile söz konusu değişkenler arasındaki ilişkileri az sayıdaki açıklayıcı kavrama (bir diğer ifade ile faktörlere) indirgemeyi hedefleyen, yapısal geçerliliğin betimlenmesine yönelik bir süreçtir (Büyüköztürk, 2014:47-50). Faktör analizinde faktörlerin elde edilmesi kullanılan yöntemlerden biri temel bileşenler analizi olup bu analizin kullanılabilmesi için veri setinin faktör analizine uygun olup olmadığının testinin yapılması gerekmektedir (Kalayc1, 2010: 321). Veri setinin bu amaçla kullanılıp kullanılamayacağının belirlenmesine yönelik olarak Bartlett testi ve Kaise-Meyer-Olkin (KMO) testleri kullanılmaktadır. Aşağıdaki Tablo 2'de çalışmaya yönelik Bartlett ve KMO testlerinin sonuçları yer almaktadır

Tablo 2: Barlett ve KMO Test Sonuçları

\begin{tabular}{|c|c|c|}
\hline \multicolumn{2}{|c|}{ Kaiser-Meyer-Olkin of Sampling Adequacy } & 0,911 \\
\hline \multirow{3}{*}{ Bartlett's Test of Sphericity } & Approx. Chi-Square & 15968,471 \\
\cline { 2 - 3 } & Df & 435 \\
\cline { 2 - 3 } & Sig & 0,000 \\
\hline
\end{tabular}

Tablo 2'den de görülebileceği üzere KMO 0,5 ten büyük ve 0,911'dir. Bartlett's testinde ise sig $<0.05$ (sig.0,000 ile anlamlı) sig <0.05'tür. Bu durumda örneklem büyüklügüüüz yeterli ve veriler normal dağılımlıdır. Bu sonuçlar veri setinin faktör analizi için uygun olduğunu göstermektedir. Verilerin faktör analizine uygun olduğu anlaşıldıktan, Temel Bileşenler Analizi yöntemi ve Varimaks Döndürmesi tekniği ile faktör döndürmeleri yardımıyla faktör analizi gerçekleştirilmiştir. Faktör analizinin sonuçları Tablo3 ve Tablo 4'de özetlenmiştir.

Faktör analizi sonucuna göre öğrencilerin yatırım kararlarını etkileyen dört önemli faktör mevcuttur. Bunların birincisi “kişilik özellikleri”'dir. Öğrencilerin kişilik özellikleri yatırım kararlarında oldukça etkilidir. İkincisi “kişinin risk karşısındaki tutumu”dur. Öğrencilerin yatırım kararlarını verirken bireysel risk algılamaları, tercihleri bir diğer ifade ile risk karşısındaki tutumları etkili olmaktadır. Üçüncüsü “yatırım araçları ile sosyal etkileşim ilişkisi”'dir. Öğrenciler yatırım yaparken yatırım araçları ve sosyal etkileşimin ilişkisinden etkilenmektedirler. Dördüncüsü "yatırım araçları ile medya ilişkisi"dir. Öğrenciler yatırım yaparken yatırım araçlarının çeşitlerinden bunların medyadaki yer alma biçimlerinden dolayısıyla ilgili yatırım araçlarının sosyal etkileşiminden etkilenmektedirler.

Tablo 3 incelendiğinde matriste yer alan dört adet faktör ve her bir değişkenin bu faktörler altındaki faktör yükleri yer almaktadır. Matriste yer alan her bir değişken, ağırlıkları açısından dikkate alınarak hangi faktör altında en yüksek değere sahipse o faktör altında gruplanmıştır. Tablo 4'de ilgili değişkenler, faktör yüklerine, ağırlıklarına bağlı olarak en yüksek ağırlık değerine sahip oldukları faktörler altında gruplandırılmıştır 


\begin{tabular}{|c|c|c|c|c|}
\hline \multicolumn{5}{|l|}{ Tablo 3: Faktör analizi } \\
\hline \multicolumn{5}{|l|}{ Döndürülmüş Faktör Matrisi } \\
\hline & \multicolumn{4}{|c|}{ Component } \\
\hline Kendinizi hırssız mı yoksa hırslı mı olarak tanımlarsınız. & .959 & .055 & -.146 & 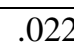 \\
\hline $\begin{array}{l}\text { Kendinizi aklına eseni yapan mı yoksa temkinli mi olarak } \\
\text { tanımlarsınız. }\end{array}$ & .958 & .100 & -.150 & .010 \\
\hline Kendinizi utangaç mı yoksa girişken mi olarak tanımlarsınız. & .937 & .255 & .089 & .021 \\
\hline Kendinizi saldırgan mı yoksa uysal mı olarak tanımlarsınız. & .933 & .141 & -.108 & .023 \\
\hline Kendinizi risk alan $\mathrm{m} 1$ yoksa risk almayan $\mathrm{m} 1$ olarak tanımlarsınız. & .928 & .300 & .037 & .270 \\
\hline Kendinizi kötümser mi yoksa iyimser mi olarak tanımlarsınız. & .925 & .268 & .105 & .010 \\
\hline $\begin{array}{l}\text { Kendinizi insanlara güvenen mi yoksa insanlara karşı şüpheci mi } \\
\text { olarak tanımlarsınız. }\end{array}$ & .923 & .293 & .023 & .035 \\
\hline $\begin{array}{l}\text { Kendinizi dürtülerine kolay kapılan mı yoksa kendini tutan mı olarak } \\
\text { tanımlarsınız. }\end{array}$ & .919 & .188 & -.215 & .025 \\
\hline Kendinizi rutini seven mi yoksa yenilikçi mi olarak tanımlarsınız. & .919 & .190 & .168 & .004 \\
\hline Kendinizi katı mı yoksa merhametli mi olarak tanımlarsınız. & .918 & .214 & -.134 & .037 \\
\hline Kendinizi kurnaz mı yoksa icten mi olarak tanımlarsınız. & .907 & .240 & .038 & .043 \\
\hline Kendinizi düzenli mi yoksa düzensiz mi olarak tanımlarsınız. & .886 & .377 & .006 & .029 \\
\hline Kendinizi dayanıklı mı yoksa dayanıksız mı olarak tanımlarsınız. & .270 & .933 & .111 & .066 \\
\hline Kendinizi kararlı mı yoksa pes eden mi olarak tanımlarsınız. & .274 & .924 & .166 & .077 \\
\hline Kendinizi kendinden emin mi yoksa güvensiz mi olarak tanımlarsınız. & .349 & .914 & .099 & .062 \\
\hline Kendinizi yavaș mı yoksa aktif mi olarak tanımlarsınız. & .357 & .904 & .089 & .067 \\
\hline Kendinizi sorumlu mu yoksa sorumsuz mu olarak tanımlarsınız. & .450 & .867 & .120 & .087 \\
\hline Kendinizi insanlara yakın $\mathrm{m} 1$ yoksa uzak $\mathrm{m} ı$ olarak tanımlarsınız. & .363 & .807 & .337 & .045 \\
\hline Kendinizi düșünceli mi yoksa kendini düșünen mi olarak tanımlarsınız. & .469 & .676 & .489 & .002 \\
\hline Kendinizi duygulu mu yoksa duygusuz mu olarak tanımlarsınız. & .512 & .661 & .514 & .008 \\
\hline Mevduat hesabının risk durumu hakkındaki düşüncenizi işaretleyiniz. & .184 & .623 & -.160 & .525 \\
\hline $\begin{array}{l}\text { Kendinizi alçak gönüllü mü yoksa kendini beğenen mi olarak } \\
\text { tanımlarsnı. }\end{array}$ & .415 & .604 & .571 & .006 \\
\hline $\begin{array}{l}\text { Gayrimenkul yatırım fonlarının risk durumu hakkındaki düşüncenizi } \\
\text { işaretleyiniz }\end{array}$ & .190 & .583 & .362 & .008 \\
\hline Sirket raporları sizi ne derecede etkiliyor. & .100 & .500 & .411 & .019 \\
\hline Gayrimenkullerin risk durumu hakkındaki düșüncenizi işaretleyiniz. & .002 & .241 & .806 & .189 \\
\hline Medyada siyasi gelişmelere ilişkin haberler sizi ne derecede etkiliyor. & .183 & .363 & .670 & .354 \\
\hline Facebook vb. sizi ne derecede etkiliyor. & .040 & .227 & .171 & .865 \\
\hline Yatırım fonlarının risk durumu hakkındaki düşüncenizi işaretleyiniz. & .337 & .331 & .108 & .791 \\
\hline Hisse senetlerinin risk durumu hakkındaki düşüncenizi işaretleyiniz. & .327 & .381 & .174 & .767 \\
\hline $\begin{array}{l}\text { Uluslararası ekonomik ve finansal gelişmeler sizi ne derecede } \\
\text { etkiliyor. }\end{array}$ & .448 & .020 & .360 & .449 \\
\hline
\end{tabular}


Tablo 4: Öğrencilerin Yatırım Davranışlarını Etkileyen Faktörler ve Faktör Yükleri

\begin{tabular}{|c|c|}
\hline Faktörler & $\begin{array}{c}\text { Faktör } \\
\text { Yüklemeleri }\end{array}$ \\
\hline \multicolumn{2}{|l|}{ Faktör 1 (Kişilik özellikleri) } \\
\hline Kendinizi hırssız mı yoksa hırslı mı olarak tanımlarsınız. & .959 \\
\hline Kendinizi aklına eseni yapan mı yoksa temkinli mi olarak tanımlarsınız. & .958 \\
\hline Kendinizi utangaç mı yoksa girişken mi olarak tanımlarsınız. & .937 \\
\hline Kendinizi saldırgan mı yoksa uysal mı olarak tanımlarsınız. & .933 \\
\hline Kendinizi risk alan $\mathrm{m} ı$ yoksa risk almayan $\mathrm{m} ı$ olarak tanımlarsınız. & .928 \\
\hline Kendinizi kötümser mi yoksa iyimser mi olarak tanımlarsınız. & .925 \\
\hline Kendinizi insanlara güvenen mi yoksa insanlara karşı şüpheci mi olarak tanımlarsınız. & .923 \\
\hline Kendinizi dürtülerine kolay kapılan mı yoksa kendini tutan mı olarak tanımlarsınız. & .919 \\
\hline Kendinizi rutini seven mi yoksa yenilikçi mi olarak tanımlarsınız. & .919 \\
\hline Kendinizi katı mı yoksa merhametli mi olarak tanımlarsınız. & .918 \\
\hline Kendinizi kurnaz mı yoksa içten mi olarak tanımlarsınız. & .907 \\
\hline Kendinizi düzenli mi yoksa düzensiz mi olarak tanımlarsınız. & .886 \\
\hline \multicolumn{2}{|l|}{ Faktör 2 (kişinin risk karşısındaki tutumu) } \\
\hline Kendinizi dayanıklı mı yoksa dayanıksız mı olarak tanımlarsınız. & .933 \\
\hline Kendinizi kararlı mı yoksa pes eden mi olarak tanımlarsınız. & .924 \\
\hline Kendinizi kendinden emin mi yoksa güvensiz mi olarak tanımlarsınız. & .914 \\
\hline Kendinizi yavaş mı yoksa aktif mi olarak tanımlarsınız. & .904 \\
\hline Kendinizi sorumlu mu yoksa sorumsuz mu olarak tanımlarsınız. & .867 \\
\hline Kendinizi insanlara yakın mı yoksa uzak mı olarak tanımlarsınız. & .807 \\
\hline Kendinizi düşünceli mi yoksa kendini düşünen mi olarak tanımlarsınız. & .676 \\
\hline Kendinizi duygulu mu yoksa duygusuz mu olarak tanımlarsınız. & .661 \\
\hline Mevduat hesabının risk durumu hakkındaki düşüncenizi işaretleyiniz & .623 \\
\hline Kendinizi alçak gönüllü mü yoksa kendini beğenen mi olarak tanımlarsınız. & .604 \\
\hline Gayrimenkul yatırım fonlarının risk durumu hakkındaki düşüncenizi işaretleyiniz & .583 \\
\hline Şirket raporları sizi ne derecede etkiliyor. & .500 \\
\hline \multicolumn{2}{|l|}{ Faktör 3 (yatırım araçları ile sosyal etkileşim iliş̧kisi) } \\
\hline Gayrimenkullerin risk durumu hakkındaki düşüncenizi işaretleyiniz & .806 \\
\hline Medyada siyasi gelişmelere ilişkin haberler sizi ne derecede etkiliyor. & .670 \\
\hline \multicolumn{2}{|l|}{ Faktör 4 (yatırım araçları ile medya ilişskisi) } \\
\hline Facebook vb. sizi ne derecede etkiliyor. & .865 \\
\hline Yatırım fonlarının risk durumu hakkındaki düşüncenizi işaretleyiniz & .791 \\
\hline Hisse senetlerinin risk durumu hakkındaki düşüncenizi işaretleyiniz & -.767 \\
\hline Uluslararası ekonomik ve finansal gelişmeler sizi ne derecede etkiliyor. & -.449 \\
\hline
\end{tabular}

Uygulanan anketteki yaş değişkeni ile diğer sorular arasındaki ilişkiye bakmak için ki-kare testi yapılmıştır. Ki-kare testine bulgular Tablo 5'den de görülebileceği üzere şu şekilde özetlenebilir;

$\mathrm{p}=0,000$ ve $\mathrm{p}<0,05$ olduğundan yaş ile öğrencilerin yaşı ile medyada siyasi gelişmelere ilişkin haberler sizi ne derecede etkiliyor sorusu arasında ilişki bulunmaktadır. Cramer's V değerine göre iki soru arasında 0,399 derecesinde ilişki vardır. 
$\mathrm{p}=0,000$ ve $\mathrm{p}<0,05$ olduğundan yaş ile uluslararası ekonomik ve finansal gelişmeler sizi ne derecede etkiliyor sorusu arasında ilişki bulunmaktadır. Cramer's $\mathrm{V}$ değerine göre iki soru arasında 0,332 derecesinde ilişki vardır.

$\mathrm{p}=0,000$ ve $\mathrm{p}<0,05$ olduğundan yaş ile şirket raporları sizi ne derecede etkiliyor sorusu arasında ilişki bulunmaktadır. Cramer's V değerine göre iki soru arasında 0,420 derecesinde ilişki vardır.

* $\mathrm{p}=0,000$ ve $\mathrm{p}<0,05$ olduğundan yaş ile yatırım fonlarının risk durumu hakkındaki düşüncenizi işaretleyiniz sorusu arasında ilişki bulunmaktadır. Cramer's V değerine göre iki soru arasında 0,295 derecesinde ilişki vardır.

$\mathrm{p}=0,000$ ve $\mathrm{p}<0,05$ olduğundan yaş ile mevduat hesabının risk durumu hakkındaki düşüncenizi işaretleyiniz sorusu arasında ilişki bulunmaktadır. Cramer's V değerine göre iki soru arasında 0,347 derecesinde ilişki vardır.

$\mathrm{p}=0,000$ ve $\mathrm{p}<0,05$ olduğundan yaş ile hisse senetlerinin risk durumu hakkındaki düşüncenizi işaretleyiniz sorusu arasında ilişki bulunmaktadır. Cramer's V değerine göre iki soru arasında 0,410 derecesinde ilişki vardır.

* $\mathrm{p}=0,000$ ve $\mathrm{p}<0,05$ olduğundan yaş ile kendinizi insanlara güvenen mi yoksa insanlara karşı şüpheci mi olarak tanımlarsınız sorusu arasında ilişki bulunmaktadır. Cramer's V değerine göre iki soru arasında 0,342 derecesinde ilişki vardır.

$\mathrm{p}=0,000$ ve $\mathrm{p}<0,05$ olduğundan yaş ile kendinizi kötümser mi yoksa iyimser mi olarak tanımlarsınız sorusu arasında ilişki bulunmaktadır. Cramer's V değerine göre iki soru arasında 0,319 derecesinde ilişki vardır. olarak tanımlarsınız sorusu arasında ilişki bulunmaktadır. Cramer's V değerine göre iki soru arasında 0,326 derecesinde ilişki vardır.

* $\mathrm{p}=0,000$ ve $\mathrm{p}<0,05$ olduğundan yaş ile kendinizi risk alan mı yoksa risk almayan mı olarak tanımlarsınız sorusu arasında ilişki bulunmaktadır. Cramer's V değerine göre iki soru arasında 0,335 derecesinde ilişki vardır.

$\mathrm{p}=0,000$ ve $\mathrm{p}<0,05$ olduğundan yaş ile kendinizi kararlı $\mathrm{m}$ yoksa pes eden mi olarak tanımlarsınız sorusu arasında ilişki bulunmaktadır. Cramer's V değerine göre iki soru arasında 0,390 derecesinde ilişki vardır. 
Tablo 5: Ki-kare Testi

\begin{tabular}{|c|c|c|c|c|c|}
\hline & & Value & $\mathrm{df}$ & \begin{tabular}{|l|} 
Asymp. \\
Sig. \\
(2-sided) \\
\end{tabular} & $\begin{array}{l}\text { Approx. } \\
\text { Sig. }\end{array}$ \\
\hline \multirow{2}{*}{$\begin{array}{l}\text { Yaş ve medyada siyasi gelişmelere } \\
\text { ilişkin haberler sizi ne derecede } \\
\text { etkiliyor }\end{array}$} & Pearson Chi-Square & $159,301^{\mathrm{a}}$ & 28 &, 000 & \\
\hline & Cramer's V & ,399 & & & ,000 \\
\hline \multirow{2}{*}{$\begin{array}{l}\text { Yaş ile uluslararası ekonomik ve } \\
\text { finansal gelişmeler sizi ne derecede } \\
\text { etkiliyor }\end{array}$} & Pearson Chi-Square & $110,078^{a}$ & 28 &, 000 & \\
\hline & Cramer's V &, 332 & & &, 000 \\
\hline \multirow{2}{*}{$\begin{array}{l}\text { Yaş ve şirket raporları sizi ne } \\
\text { derecede etkiliyor }\end{array}$} & Pearson Chi-Square & $175,982^{\mathrm{a}}$ & 28 &, 000 & \\
\hline & Cramer's V & .420 & & & ,000 \\
\hline \multirow{2}{*}{$\begin{array}{l}\text { Yaş ve yatırım fonlarının risk } \\
\text { durumu hakkındaki düşüncenizi } \\
\text { işaretleyiniz }\end{array}$} & Pearson Chi-Square & $87,086^{\mathrm{a}}$ & 28 &, 000 & \\
\hline & Cramer's V &, 295 &, 000 & ,295 & 000 \\
\hline \multirow{2}{*}{$\begin{array}{l}\text { Yaş ve mevduat hesabının risk } \\
\text { durumu hakkındaki düşüncenizi } \\
\text { işaretleyiniz }\end{array}$} & Pearson Chi-Square & $120,278^{a}$ & 28 &, 000 & \\
\hline & Cramer's V &, 347 & & & ,000 \\
\hline \multirow{2}{*}{$\begin{array}{l}\text { Yaş ve hisse senetlerinin risk durumu } \\
\text { hakkındaki düşüncenizi işaretleyiniz }\end{array}$} & Pearson Chi-Square & $168,468^{a}$ & 28 &, 000 & \\
\hline & Cramer's V &, 410 & & & , 000 \\
\hline \multirow{2}{*}{$\begin{array}{l}\text { Yaş ve kendinizi insanlara güvenen } \\
\text { mi yoksa insanlara karşı şüpheci mi } \\
\text { olarak tanımlarsınız }\end{array}$} & Pearson Chi-Square & 117,07 & $1^{\mathrm{a}}$ & 28 & \\
\hline & Cramer's V &, 342 & & &, 000 \\
\hline \multirow{2}{*}{$\begin{array}{l}\text { Yaş ve kendinizi kötümser mi yoksa } \\
\text { iyimser mi olarak tanımlarsınız }\end{array}$} & Pearson Chi-Square & $101,488^{a}$ & 28 &, 000 & \\
\hline & Cramer's V & .319 & & & ,000 \\
\hline \multirow{2}{*}{\begin{tabular}{|l|}
$\begin{array}{l}\text { Yaş ve kendinizi utangaç } \mathrm{m} 1 \text { yoksa } \\
\text { girişken mi olarak tanımlarsınız }\end{array}$ \\
\end{tabular}} & Pearson Chi-Square & $106,237^{\mathrm{a}}$ & 28 &, 000 & \\
\hline & Cramer's V & .326 & & & ,000 \\
\hline \multirow{2}{*}{$\begin{array}{l}\text { Yaş ve kendinizi risk alan mı yoksa } \\
\text { risk almayan mı olarak tanımlarsınız }\end{array}$} & Pearson Chi-Square & $112,057^{\mathrm{a}}$ & 28 &, 000 & \\
\hline & Cramer's V &, 335 & & &, 000 \\
\hline \multirow{2}{*}{$\begin{array}{l}\text { Yaş ve kendinizi kararlı mı yoksa } \\
\text { pes eden mi olarak tanımlarsınız }\end{array}$} & Pearson Chi-Square & $152,007^{\mathrm{a}}$ & 28 &, 000 & \\
\hline & Cramer's V & .390 & & & ,000 \\
\hline
\end{tabular}

\section{Sonuç}

Çalışma bulguları ele alındığında öğrencilerin yatırım yaparken kişilik özelliklerinden önemli derecede etkilendikleri söylenebilir. Bireyin kişilik özellikleri yatırım yaparken riski algılamasında ve kararında oldukça etkilidir. Hırslı bir yatırımcının risk algılaması ve yatırım kararı, hırssız bir yatırımcıya göre farklılık göstermekte bilmektedir. Bu durum yatırımcıların risk tercihleri ile ilintili olup bireylerin geçmiş deneyim ve algılamalarına bağlı bir farklılaşmadır. Benzer şekilde iyimserlikte finansal kararlar üzerinde önemli bir belirleyicidir. İyimser bir yatırımc1 kendi görüş ve düşüncesini, bilgisini abartarak sonuçların kötü olma olasılığını, dolayısıyla riski de az görmektedir. Kötümser bir yatırımcı açısından bakıldığında ise durum tam tersidir. $\mathrm{Bu}$ nedenlerle iki yatırımcının riski algılamalarındaki farklılık, yatırım kararlarında farklılaşmaya neden olmaktadır. Öğrencilerin risk karşısındaki tutumu yatırım yaparken önemli bir faktördür. Yatırımcıların kararlarını verirken risk faktörünün etkisi oldukça fazladır. Yatırımcıların risk karşısındaki tutumu ve riski algılama biçimi almış oldukları finansal nitelikli kararlarını etkilemektedir.

Çalışma neticesinde üniversite öğrencilerinin yatırım yaparken ilgili yatırım araçları ile sosyal etkileşimin ilişkisinden yoğun biçimde etkilendiği görülmektedir. Sosyal bir varlık olan bireyin özellikle içinde bulunduğumuz yüzyılda artan bir sosyal etkileşim içinde olduğu yadsınamaz bir gerçektir. İnsanlar bulundukları toplumdan ve çevrelerinden etkilenmekte, 
çevresinde yaşayan insanların davranışlarını öğrenmekte ve karar alırken sürü psikolojisine uygun hareket edebilmektedirler. Basit bir anlatımla bireysel yatırımcılar hangi yatırım aracına yatırım yapacaklarına kara verirken ailelerinin, arkadaşlarının fikirlerini almakta, onlarla bilgi paylaşımı yaparak karar vermektedirler. $\mathrm{Bu}$ bağlamda yatırımcıların sosyalleşme düzeyi tercih ettikleri yatırım araçları üzerinde önemli bir etkisi mevcuttur. Çalışma bulgularına göre yatırım araçları ve medyanın ilişkisinin, öğrencilerin yatırım yaparken etkilendikleri en önemli faktörlerden biri olduğu görülmüştür. İnternet, gazete, radyo, televizyon, dergi gibi yazılı ve görsel kitle iletişim araçları olarak tarif edilebilecek medya insanların davranışlarını büyük ölçüde etkilemektedir. Medyada yer alan, yatırım dünyası ile ilgili yayınlar, uzman fikirleri vb. muhtelif bilginin toplumsal bir dalga etkisi yarattığı söylenebilir. Her ne kadar söz konusu bilginin niteliği, doğruluğu ve güvenirliliği tartışmaya açık bir husus olsa da bireyleri farklı düzeylerde de olsa etkilediği söylenebilir. Çalışma bulguları dikkate alındığında özellikle üniversite gençliğinin söz konusu etkileşimden daha yoğun bir biçimde etkilendiği görülmektedir. Benzer şekilde çalı̧mada öğrencilerin yaşları ile öğrencilerin medyada siyasi gelişmelere ilişkin haberlerden, uluslararası ekonomik ve finansal gelişmelerden, şirket raporlarından etkilenme derecesi arasında anlamlı bir ilişki belirlenmiştir. Buna ek olarak öğrencilerin yaşları ile öğrencilerin yatırım fonlarının, mevduat hesaplarının ve hisse senetlerinin risk durumu hakkındaki düşünceleri arasında ilişki bulunmuştur.

\section{Kaynakça}

Ajdukovic, I., Max, S., Perchot, R., \& Spiegelman, E. (2018). The Economic Psychology of Gabriel Tarde: Something new for behavioral economics?. Journal of Behavioral Economics for Policy, 2(1), 5-11.

Aren S., Kaya M. İ. Y., \& Dinç Aydemir S. (2014). Davranışsal finans: Finans teorisinde farklı bir perspektif, Leges Bankacllık ve Finans Hukuku Dergisi, 39-51.

Aytekin Ö.G.Y. E. ve Aygün M. (2016), Finansta yeni bir alan davranışsal finans, Yüzüncü Yıl Üniversitesi İktisadi ve İdari Bilimler Fakültesi Dergisi, (2), 143-156.

Barberis, N., Shleifer, A., \& Vishny, R. (1998). A model of investor sentiment. Journal of Financial Economics, 49(3), 307-343.

Betts, C., \& Devereux, M. B. (2000). Exchange rate dynamics in a model of pricing-to-market. Journal of international Economics, 50(1), 215-244.

Böyükaslan, A. (2012). Bireysel yatırımcıları finansal yatırım kararına yönlendiren faktörlerin davranışsal finans açısından incelenmesi: Afyonkarahisar örneği. Yayınlanmamış Yüksek Lisans Tezi. Afyon Kocatepe Üniversitesi.

Büyüköztürk, Ş. (2002). Faktör analizi: Temel kavramlar ve ölçek geliştirmede kullanımı. Kuram ve uygulamada ĕgitim yönetimi, 32(32), 470-483.

Chen, S. L., Jackson, J. D., Kim, H., \& Resiandini, P. (2014). What drives commodity prices?. American Journal of Agricultural Economics, 96(5), 1455-1468.

Clark, J.M. (1918), Economics and modern psychology, The Journal of Political Economy, 26(1), $1-30$.

Cochrane, J. H. (2011). How did Paul Krugman get it so wrong?. Economic Affairs, 31(2), 36-40.

Cutler, D. M., Poterba, J. M., \& Summers, L. H. (1989). International evidence on the predictability of stock returns. Unpublished manuscript, MIT.

Çiğdem, Ç. (2013). İMKB'de işlem yapan yatırımcıların davranışlarını belirlemeye yönelik bir araştırma. Yayınlanmamış Yüksek Lisans Tezi. Dokuz Eylül Üniversitesi. 
Daft, R. L. (2010). Understanding the theory and design of organizations, 10th Edition. USA: South-Western CENGAGE Learning.

Dixit, A.K. (1989), Hysteresis, import penetration and exchange rate pass-through, Quarterly Journal of Economics, 104(2), 205-228.

Dornbusch, R. (1987). "Purchasing power parity", the New Palgrave: A Dictionary of Economics, Londra: Macmillan, 1075-1085.

Engel, C. \& J.H. Rogers (1996). How wide is the border?, American Economic Review, 86(5), $1112-1125$.

Fama, E.F. (1970). Efficient capital markets: a review of theory and empirical work, The Journal of Finance, 25(2), 383-417.

Ferson, W. E., \& Harvey, C. R. (1993). The risk and predictability of international equity returns. Review of financial Studies, 6(3), 527-566.

Ghosh, A.R. \& H.C. Wolf (1994), "Pricing in international markets: lessons from the economist", National Bureau of Economic Research Working Paper, 4806.

Gözgör, G. (2015). Tek fiyat kanunu ve satın alma gücü paritesi hipotezine ilişkin ampirik bulgular: bir literatür taramas1, Sosyoekonomi Dergisi, 23(24), 23-37.

Gümüş, F. B., Koç, M., \& Agalarova, M. (2013). Bireysel yatırımcıların yatırım kararları üzerinde etkli olan demografik ve psikolojik faktörlerin tespiti üzerine bir çalışma: türkiye ve azerbaycan uygulaması. Kafkas Üniversitesi İktisadi ve İdari Bilimler Fakültesi Dergisi, 71-94.

Gürsoy, C. T. (2014). Finansal yönetim ilkeleri. İstanbul: Beta.

Hamurcu, Ç., \& Aslanoğlu, S. (2016). Bilgi teknolojileri-iletişim sektörü çalışanları üzerinde davranışsal finans eğilimlerin etkileri: ölçek çalışması. Ulakbilge Sosyal Bilimler Dergisi, 31-53.

Hayta, A. B. (2014). Bireysel yatırımcıların finansal risk algısına etki eden psikolojik önyargılar. Türkiye Sosyal Araştırmalar Dergisi, 329-352.

Huber, F. (2016). Forecasting exchange rates using multivariate threshold models. The BE Journal of Macroeconomics, 16(1), 193-210.

International Association for Research in Economic Psychology (2012). What is 1arep? Retrieved from. Erişim Tarihi: 20.09.2019, http://www.iarep.org/

Kahneman, D., \& Riepe, M. (1998). Aspects of investor psychology. Journal of Portfolio Management, 52-65.

Kalayc1, Ş. (Ed.). (2010). SPSS uygulamalı çok değiş̧kenli istatistik teknikleri. Ankara. Asil Yayın.

Kıyılar, M. ve Akkaya, M. (2016). Davranışsal finans. İstanbul: Literatür.

Knetter, M.M. (1993). "International comparisons of price-to-market behavior", American Economic Review, 83(3), 473-486.

Krugman, P.R. (1987). "Pricing to market when the exchange rate changes", Real-financial Linkages among Open Economies, Cambridge, MA: MIT Press, 49-70.

Le Bon, G. (1896). The crowd: A study of the popular mind. London: Ernest Benn. English edition originally published. 
O'Connell, P.G. \& S-J. Wei (2002), The bigger they are, the harder they fall: Retail prices differences across us cities, Journal of International Economics, 56(1), 21-53.

Olper, A., \& Raimondi, V. (2008). Agricultural market integration in the OECD: A gravity-border effect approach. Food Policy, 33(2), 165-175.

Parsley, D. C., \& Wei, S. J. (2001). Explaining the border effect: the role of exchange rate variability, shipping costs, and geography. Journal of International Economics, 55(1), 87 105.

Porta, R. L., Lakonishok, J., Shleifer, A., \& Vishny, R. (1997). Good news for value stocks: Further evidence on market efficiency. The Journal of Finance, 52(2), 859-874.

Prast, H. M. (2004). Investor psychology: A behavioural explanation of six finance puzzles. Amsterdam: De Nederlandsche Bank.

Rogoff, K.S. \& K.A. Froot \& M. Kim (2001), “The law of one price over 700 years”, International Monetary Fund Working Paper, 174.

Sansar, N. G. (2016). Değişen Finansal Akımlar: Rasyonalizmden Davranışsal Finans Yaklaşımına. Ístanbul Gelişim Üniversitesi Sosyal Bilimler Dergisi, 3(2), 135-150.

Sarno, L., Taylor, M. P., \& Chowdhury, I. (2004). Nonlinear dynamics in deviations from the law of one price: a broad-based empirical study. Journal of International Money and Finance, 23(1), 1-25.

Seyidoğlu, H. (2001). Uluslararası finans, Güzem Yayınları Geliştirilmiş 3. baskı İstanbul, s.100

Shleifer, A. (2000). Inefficient markets:An introduction to behavioral finance, Oxford University Press.

Simon, H. A. (1967). Motivational and emotional controls of cognition. Psychological review, 74(1), 29.

Simon, H. A. (1987). Decision making and organizational design: organization theory, selected readings, Second Edition, New York: Penguin Books.

Sümer, E. \& Aybar, Ş. (2016). Etkin piyasalar hipotezinin, finansal piyasaları açıklamadaki yetersizliği ve davranışsal finans. Erzincan Üniversitesi Sosyal Bilimler Enstitüsü Dergisi, 9(2), 75-84.

Tarde, G. (1902). La psychologie 'economique. Psychologie économique (Vol. 2). Félix Alcan, Éd., Ancienne Libr. Germer Baillière et Cie..

Tomak, S. (2011). Girişimcilik ve bilişsel yanlılık. Girişimcilik ve Kalkınma Dergisi, 59,72-95.

Tong, H. (1990). Nonlinear time series: A dynamical system approach, Oxford: Oxford University Press

Tufan, E. (2008). Davranışsal Finans. Ankara: İmaj.

Tversky, A. \& Kahneman, D. (1974). Judgment under uncertainty: Heuristics and biases. Science, 185(4157), 1124-1131.

Uronen, P., (2011) 'Rahoituksen perusteet', sijoitusstrategiat, ('The basics of finance' investment strategies), [Online]. Erişim Tarihi: 20.09.2019, Available: https://noppa.lut.fi/noppa/opintojakso/.../lisatty/sijoitusstrategiat.doc

Yeşildağ Ğ, E. ve Özen, E. (2015). Uşak ilindeki hisse senedi yatırımcılarının profili ve yatırım kararlarını etkileyen demografik ve sosyo-ekonomik faktörlerin analizi. Journal of Accounting, Finance and Auditing Studies, 1(2), 78-102. 